\title{
Penentuan Jarak Terpendek Pada Jalur Pengiriman Musae Chips Dengan Menggunakan Algoritma Genetika
}

\author{
Muhammad Bahrul Arif \\ Teknologi Informasi \\ Politeknik Negeri Jember \\ Jember, Indonesia \\ bahrularif08@gmail.com \\ Intan Kemala Pertiwi \\ Teknologi Informasi \\ Politeknik Negeri Jember \\ Jember, Indonesia \\ intankemala07@gmail.com \\ Trismayanti Dwi Puspitasari \\ Teknologi Informasi \\ Politeknik Negeri Jember \\ Jember, Indonesia \\ trismayanti@polije.ac.id
}

\author{
Rangga Akhir Aprian \\ Teknologi Informasi \\ Politeknik Negeri Jember \\ Jember, Indonesia \\ rangga.aprian03@gmail.com \\ Mohammad Naufal Ramadhan \\ Teknologi Informasi \\ Politeknik Negeri Jember \\ Jember, Indonesia \\ ramadhannaufal628@gmail.com
}

\author{
Rizky Cahyasanti \\ Teknologi Informasi \\ Politeknik Negeri Jember \\ Jember, Indonesia \\ santirizkycahya@gmail.com \\ Eldwin Hendrasiva \\ Teknologi Informasi \\ Politeknik Negeri Jember \\ Jember, Indonesia \\ eldwinhsiva@gmail.com
}

\begin{abstract}
Combination of good path distribution by land can optimize travel time and costs. However, not all of these path distribution combinations will provide the best solution. The study was conducted to determine the distribution of goods so that the best solution is achieved. To simplify the process of determining the goods distribution channel, it is supported by software development. Genetic algorithms that have reliability in producing optimal solutions can be used to solve this problem. The application of the genetic algorithm method is applied in software. In the software that is built, there are several inputs needed, namely: cities destination distribution as the initial chromosome number, number of generations, crossover probability and probability of mutation. The result of processing is a combination of goods distribution lines to be taken which represent the solution to this problem. Only the best chromosomes will be given as a result. Through the software that was built, the determination of goods distribution lines is expected to be better and can optimize the time and cost of travel. Based on the research, 5 road combinations are used as chip distribution routes used for testing. This study results from the first fitness gene get the highest fitness 7.4, fitness lowest 5.6 and the second gene get the highest fitness 9.3, fitness lowest 5.6.
\end{abstract}

Keywords—Distribution; Genetic Algorithm; Software.

Abstrak - Kombinasi jalur distribusi barang berdasarkan jalur darat yang baik dapat mengoptimalkan waktu dan biaya perjalanan. Namun, tidak semua kombinasi jalur ini akan memberikan solusi terbaik. Penelitian ini dilakukan untuk mengetahui jalur distribusi barang sehingga solusi terbaik tercapai. Untuk menyederhanakan proses penentuan jalur distribusi barang, maka perlu didukung sebuah perangkat lunak. Algoritma genetika yang memiliki keandalan dalam menghasilkan solusi optimal dapat digunakan untuk menyelesaikan masalah ini. Penerapan metode algoritma genetika dapat diterapkan dalam perangkat lunak. Dalam perangkat lunak yang dikembangkan, ada beberapa input yang dibutuhkan, yaitu: distribusi tujuan kota sebagai nomor kromosom awal, jumlah generasi, probabilitas crossover dan probabilitas mutasi. Hasil pengolahan adalah kombinasi dari jalur distribusi barang yang akan diambil yang merupakan solusi untuk masalah ini. Hanya kromosom terbaik yang akan diberikan sebagai hasilnya. Melalui perangkat lunak yang dikembangkan, penentuan jalur distribusi barang diharapkan menjadi lebih baik dan dapat mengoptimalkan waktu dan biaya perjalanan. Berdasarkan penelitian, 5 kombinasi jalan digunakan sebagai rute distribusi chip yang digunakan untuk pengujian. Hasil penelitian menunjukkan fitness gen pertama mendapatkan nilai fitness tertinggi 7,4 , nilai fitness terendah 5,6 dan fitness gen kedua menunjukkan nilai fitness tertinggi $\mathbf{9 , 3}$, nilai fitness terendah $\mathbf{5 , 6}$. lunak.

Keywords- Algoritma genetika; Distribusi; Perangkat

\section{PENDAHULUAN}

Transportasi merupakan bagian yang tidak terpisahkan dari semua sektor industri. Hal itu di karenakan hampir semua sektor industri selalu mencakup proses distribusi dan logistik. Bahan bakar dan waktu yang digunakan untuk mengirim merupakan biaya cukup besar untuk industri yang melakukan disrtibusi dengan frekuensi rutin ke banyak lokasi. Transportasi selalu memakan biaya, dan oleh karena itu mempengaruhi biaya produksi dan distribusi hingga 10$20 \%$ dari total biaya suatu produk. Oleh karena itu, efisiensi di bidang transportasi sangat penting dan dapat secara signifikan mengurangi total biaya produksi dan distribusi [1].

Masalah transportasi adalah bagian dari "operation research" yang membahas tentang distribusi barang dengan jarak terpendek dari suatu tempat ke tempat lain. Saluran distribusi adalah serangkaian organisasi yang saling tergantung yang terlibat dalam proses untuk menjadikan barang atau jasa siap untuk digunakan atau dikonsumsi [3]. Dari dua jurnal yang ada semuanya membahas terkait dengan bagaimana cara mencari jarak terpendek untuk jalur pendistribusian dengan menerapkan algoritma genetika. 
Algoritma genetika merupakan metode yang cocok untuk digunakan dan diterapkan pada studi kasus digunakan. Algoritma genetika dapat menghasilkan keluaran hasil pemerosesan data yang optimal. Dengan penerapan konsep evolusi biologis maka akan diperoleh output hasil berupa kombinasi jalur distribusi barang yang optimal. Pada perangkat lunak yang dibuat akan dimasukan kombinasi lokasi dengan tujuan pengiriman barang. selanjutnya dilakukan pengujian perangkat lunak dengan merapkan parameter yang terdapat pada algoritma genetika [4] .

Tujuan yang ingin dicapai dalam penelitian ini adalah untuk menentukan jalur distribusi barang yang terbaik dengan menggunakan algoritma genetika. Dalam penentuan jalur tersebut difokuskan pada pendistribusian barang ke agen-agen yang ada didaerah Jember kec. Sumbersari Distribusi yang digunakan dalam penelitian ini hanya ada di Jember dan jalan awal merupakan jalan tujuan awal dan akhir dari jalur distribusi. Dalam penelitian ini, terdapat 12 jalan yang menjadi input dalam satu jalur distribusi.

\section{ALGORITMA GENETIKA}

Algoritma Genetika adalah mencari penyelesaian secara menyeluruh bukan per point saja. Algoritma Genetika akan menyelesaikan permasalahan secara menyeluruh, dengan demikian akan diperoleh hasil yang seoptimal mungkin [5].

Algoritma genetika merupakan suatu metode pencarian yang didasarkan pada mekanisme dari seleksi dan genetika natural. Metode seleksi pada algoritma genetika ada bermacam-macam, antara lain RouletteWheel, Elitism, Sigma Scaling, Boltzmann, Rank Selection, Tournament Selection, dan Steady-State Selection [6].

Langkah menentukan rute terpendek menggunakan algoritma genetika dengan metode roulette wheel selection adalah mendefinisikan rute ke dalam individu dalam sebuah populasi, menghitung nilai fitness individu, menentukan induk dari individu dengan seleksi roulette wheel selection, melakukan order-crossover pada induk yang terpilih, menghasilkan individu baru dengan swapping mutation, menyusun populasi baru sampai memperoleh individu dengan nilai fitness optimum [7].

Roulete Wheel selection adalah seleksi berdasarkan kualitas individual. Semakin berkualitas individu semakin besar kemungkinan individu ini terpilih untuk menjadi anggota pada populasi yang baru [8].

Pindah Silang (crossover) adalah operator dari algoritma genetika yang melibatkan dua induk untuk membentuk kromosom baru. Pindah silang menghasilkan keturunan baru dalam ruang pencarian yang siap diuji [9].

Proses mutasi ini dilakukan setelah proses rekombinasi dengan cara memilih kromosom yang akan dimutasi secara acak, dan kemudian menentukan titik mutasi pada kromosom tersebut secara acak pula. Banyaknya kromosom yang akan mengalami mutasi dihitung berdasarkan probabilitas mutasi yang telah ditentukan terlebih dahulu. Apabila probabilitas mutasi adalah $100 \%$ maka semua kromosom yang ada pada populasi tersebut akan mengalami mutasi. Sebaliknya, jika probabilitas mutasi yang digunakan adalah 0\% maka tidak ada kromosom yang mengalami mutasi pada populasi tersebut [4] .

Data type (tipe data) adalah klasifikasi atau jenis dari suatu informasi atau data tertentu. Setiap nilai yang dimanipulasi oleh Oracle memiliki sebuah tipe data masingmasing. Tipe data dari sebuah nilai tersebut diasosiasikan dengan nilai properti yang diset tetap. Tipe data FLOAT adalah subtipe dari NUMBER. Hal ini dapat ditentukan dengan atau tanpa presisi, yang memiliki definisi yang sama dengan yang dimiliki tipe data NUMBER dan dapat berkisar dari 1 sampai 126. Skala yang belum bisa ditentukan, tetapi diinterpretasikan dari data. Setiap nilai FLOAT membutuhkan 1 sampai dengan 22 byte [10].

\section{METODE PENELITIAN}

Proses perhitungan untuk menentukan jarak terdekat pengiriman Musae Chips dalam penelitian ini menggunakan tahapan - tahapan yang terdapat pada algoritma genetika. Dapat dilihat pada gambar berikut.

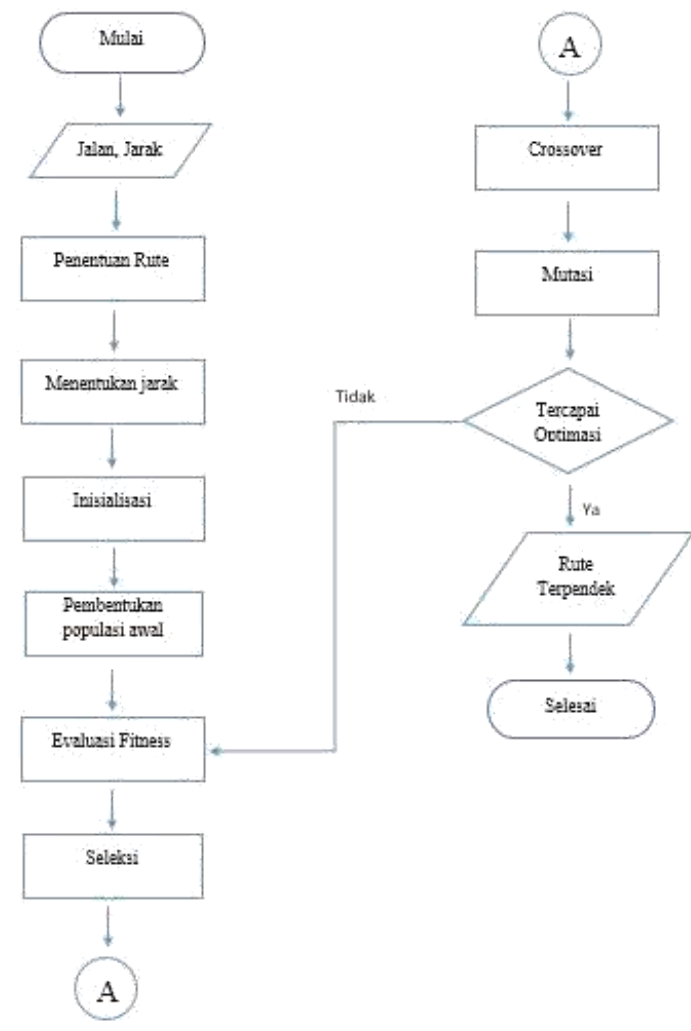

Gambar 1. Flowchart Algoritma Genetika Penentuan Jalur Terpendek

\section{A. Menentukan Rute}

Untuk menentukan rute pengiriman maka dibuatlah studi kasus berdasarkan salah satu kondisi dari keadaan dilapangan sebenarnya di kecamatan Sumbersari. Rute yang di tentukan adalah pengiriman musae chips dari Jl. Mastrip menuju Jl. Sumatra. Maka pengiriman ini akan melauli rute berikut Jl. Mastrip, Jl. Kalimantan, Jl. Riau, Jl. Jawa, J1. Sumatra.

\section{B. Menentukan Jarak dan Panjang Lintasan}

Penentuan jarak dari masing masing jalan maupun rute pengiriman kami menggunakan data berdasarkan data jarak yang terdapat pada google maps. Sehingga dapat diperoleh jarak yang akurat. Mencari panjang lintasan rute pengiriman ini merupakan hal yang pertama yang menjadi penentu studikasus yang akan dibahas. 


\section{Teknik Proses Seleksi}

Proses seleksi merupakan proses yang mempunyai peranan penting dalam algoritma genetika. Melalui proses seleksi akan diperoleh populasi mulai dari yang paling rendah hingga terbaik. Proses seleksi ini akan terus terjadi hingg ditemukan populasi terbaik. Dapat juga membatasi proses perulangan untuk penentuan banyak populasi.

\section{Teknik Proses Menentukan Fitness}

Untuk menghitung dan menentukan nilai dari fitness adakah dengan menjumlahkan jarak pada rute jalan yang dilalui. Tetapi sebelum menentukan atau menhitung fitness sangat perlu dilakukan penentuan kromosom, gen dan juga populasi yang ada. Setelah itu baru proses penentuan nilai fitness dapat dilakukan.

\section{E. Teknik Proses Menentukan Probabilitas}

Untuk menentukan probabilitas dapat menggunakan rumus perhitungan sebagai berikut.

$$
\mathrm{P}[\mathrm{i}]=\mathrm{Q}[\mathrm{i}] / \text { Total }
$$

$\mathrm{P}$ [i] merupakan probabilitas yang akan dicari, Q[i] merupakan nilai yang di peroleh dari seleksi kromosom / dibagi dengan nilai total dari perhitungan kromosom.

\section{F. Teknik Proses Menentukan Komulatif}

Penentuan komulatif ini dilakukan karena proses seleksi yang digunakan adalah roullete wheel, oleh karena itu perlu untuk mencari nilai komulatif dari probabilitas yang ada. Cara untuk mencari komulatif adalah dengan menghitnung berdasarkan dari penjumlahan nilai probabilitas. Komulatif di simbolkan sebagai berikut C[i]. Untuk komulatif pertama diperoleh dari hasli probabilitas pertama. Selanjutnya $C[2]$ di peroleh dari hasil probabilitas pertama ditambah dengan probabilitas kedua. Selanjutnya $\mathrm{C}[3]$ di peroleh dari hasil $\mathrm{C}[2]$ ditambah dengan probabilitas ke 3, begitu selanjutnya.

\section{G. Teknik Proses Roullete Wheel}

Proses roullete whell merupakan proses seleksi yang akan membangkitkan nilai acak $\mathrm{R}$ antara $0-1$. Jika $\mathrm{R}[\mathrm{k}]<\mathrm{C}[\mathrm{k}]$ maka kromosom ke - $\mathrm{k}$ sebagai induk, selain itu pilih kromosom ke - $\mathrm{k}$ sebagai induk dengan syarat $\mathrm{C}[\mathrm{k}-1]<\mathrm{R}[\mathrm{k}]<\mathrm{C}[\mathrm{k}]$.

\section{H. Teknik Proses Crossover}

Pindah silang pada TSP dapat diimplementasikan dengan skema order crossover. Pada skema ini, satu bagian kromosom dipertukarkan dengan tetap menjaga urutan Jalan yang bukan bagian dari kromosom tersebut. Kromosom yang dijadikan induk dipilih secara acak dan jumlah kromosom yang dicrossover dipengaruhi oleh parameter crossover probability (ñc).

Misal menentukan $\tilde{\mathrm{nc}}=25 \%$, maka diharapkan dalam 1 generasi ada 50\% (3 kromosom) dari populasi mengalami crossover. Untuk itu perlu untuk membangkitkan nilai acak $\mathrm{R}$ sebayak jumlah populasi yang ada.

\section{Teknik Proses Mutasi}

Pada kasus TSP yang digunakan dalam penelitian ini digunakan proses mutasi swapping mutation. Jumlah kromosom yang mengalami mutasi dalam satu populasi ditentukan oleh parameter mutation rate(ñm). Mutasi dilakukan dengan cara melakukan penukaran gen dengan cara memilih secara acak dengan gen sesudahnya. Jika gen tersebut berada di akhir kromosom, maka ditukar dengan gen yang pertama.

\section{HASIL DAN PEMBAHASAN}

TABEL 1

PROSES MUTASI

\begin{tabular}{|c|l|c|c|c|c|}
\hline No & \multicolumn{1}{|c|}{ Nama Jalan } & Jl.Sumatera & Jl.Jawa & Jl.Riau & Jl. Kalimantan \\
\hline 1 & Jl.Sumatera & & 0,6 & 2,2 & 1,3 \\
\hline 2 & Jl.Kalimantan & 1,3 & 1,3 & 2,1 & \\
\hline 3 & Jl.Jawa & 1,3 & & 0,8 & 1,2 \\
\hline 4 & $\begin{array}{l}\text { Jl.Letjen } \\
\text { Panjaitan }\end{array}$ & 1,3 & 2,6 & 2,0 & 2,6 \\
\hline 5 & Jl.Riau & 2,2 & 0,8 & & 2,1 \\
\hline 6 & Jl.Danau Toba & 2,3 & 2,9 & 1,9 & 1,0 \\
\hline 7 & Jl.Letjen Suprapto & 1,5 & 2,8 & 3,9 & 2,7 \\
\hline 8 & Jl.Mastrip & 2,0 & 1,8 & 0,9 & 0,7 \\
\hline 9 & Jl.Karimata & 2,6 & 1,2 & 1,1 & 2,5 \\
\hline 10 & Jl.Baturaden & 2,7 & 2,6 & 1,7 & 1,5 \\
\hline 11 & Jl.Tidar & 3,9 & 2,5 & 1,8 & 3,8 \\
\hline 12 & Jl.Kaliurang & 3,5 & 2,1 & 1,2 & 2,7 \\
\hline 13 & Jl.Bangka & 2,0 & 0,6 & 0,3 & 1,8 \\
& Belitung & & & & \\
\hline
\end{tabular}

Dimisalkan jalur pengiriman musae chips yang akan ditempuh adalah Jl. Mastrip - Jl. Kalimantan - Jl. Riau - Jl. Jawa - J1. Sumatra. Kemudian dilakukan teknik encoding dengan menginisialisasi kota-kota tersebut dengan angka yaitu Jl. Mastrip (1) - Jl. Kalimantan (2) - Jl. Riau (3) - Jl. Jawa (4) - Jl. Sumatra (5). Didapatkan gennya adalah Jl. Kalimantan (2) - Jl. Riau - Jl. Jawa (4) - Jl. Sumatra (5), Jl. Mastrip (1) tidak dimasukkan kedalam gen karena asumsinya adalah bahwa kota asal adalah juga merupakan kota akhir tujuan distribusi barang.

\section{A. Inisialisasi}

Kemudian misalkan ada enam populasi dalam satu generasi yaitu :

- Kromosom[1] : [Jl. Kalimantan - Jl. Jawa - Jl. Riau - Jl. Sumatra ] atau [B D C E]

- Kromosom[2] : [Jl. Jawa - Jl. Kalimantan - Jl. Sumatra - Jl. Riau ] atau [D B E C]

- Kromosom[3] : [Jl. Kalimantan - Jl. Sumatra - Jl. Riau - J1. Jawa ] atau [ B E C D]

- Kromosom[4] : [Jl. Sumatra - Jl. Jawa - Jl. Kalimantan - Jl. Riau ] atau [E D B C]

- Kromosom[5] : [Jl. Riau - Jl. Sumatra - Jl. Jawa - Jl. Kalimantan ] atau [C E D B]

- Kromosom[6] : [Jl. Jawa - Jl. Riau - Jl. Kalimantan - Jl. Sumatra] atau [D C B E]

\section{B. Evaluasi Kromosom}


Kemudian menghitung nilai fitness dari tiap kromosom yang telah dibangkitkan pada langkah a di atas.

- Fitness[1] $=\mathrm{AB}+\mathrm{BD}+\mathrm{DC}+\mathrm{CE}+\mathrm{EA}=0.7+1.2+$ $0.8+2.2+2=6.9$

- Fitness[2] $=\mathrm{AD}+\mathrm{DB}+\mathrm{BE}+\mathrm{EC}+\mathrm{CA}=1.8+1.2+1.3$ $+2.2+0.9=7.4$

- Fitness[3] $=\mathrm{AB}+\mathrm{BE}+\mathrm{EC}+\mathrm{CD}+\mathrm{CA}=0.7+1.3+2.2$ $+0.8+1.8=6.8$

- Fitness $[4]=\mathrm{AE}+\mathrm{EB}+\mathrm{DB}+\mathrm{BC}+\mathrm{CA}=2+0.6+1.2+$ $2.1+0.9=6.8$

- Fitness[5] $=\mathrm{AC}+\mathrm{CE}+\mathrm{ED}+\mathrm{DB}+\mathrm{BA}=0.9+2.2+0.6$ $+1.2+0.7=5.6$

- Fitness[6] $=\mathrm{AD}+\mathrm{DC}+\mathrm{CB}+\mathrm{BE}+\mathrm{EA}=1.8+0.8+2.1$ $+1.3+2=8$

C. Seleksi Kromosom

$\mathrm{Q}[\mathrm{i}]=1 /$ Fitness $[\mathrm{i}]$

$\mathrm{Q}[1]=1 / 6.9=0.145$

$\mathrm{Q}[2]=1 / 7.4=0.135$

$\mathrm{Q}[3]=1 / 6.8=0.147$

$\mathrm{Q}[4]=1 / 6.8=0.147$

$\mathrm{Q}[5]=1 / 5.6=0.178$

$\mathrm{Q}[6]=1 / 8=0.125$

Total $=0.145+0.135+0.147+0.147+0.178+0.125$ 0.877

Untuk mencari probabilitas menggunakan rumus berikut :

$\mathrm{P}[\mathrm{i}]=\mathrm{Q}[\mathrm{i}] /$ Total $(\mathrm{Q})$

$\mathrm{P}[1]=0,145 / 0,877=0,165$

$\mathrm{P}[2]=0,135 / 0,877=0,153$

$\mathrm{P}[3]=0,147 / 0,877=0,167$

$\mathrm{P}[4]=0,147 / 0,877=0,167$

$\mathrm{P}[5]=0,178 / 0,877=0,203$

$\mathrm{P}[6]=0,125 / 0,877=0,142$

Dari probabilitas di atas terlihat bahwa kromosom ke-1 memiliki fitness paling kecil oleh karena itu memiliki probabilitas untuk terpilih pada generasi selanjutnya lebihbesar daripada kromosom lainnya. Untuk proses seleksi menggunakan roulettewheel, untuk itu terlebih dahulu mencari nilai komulatif dari probabilitasnya.

$$
\begin{aligned}
& \mathrm{C}[1]=0,165 \\
& \mathrm{C}[2]=0,165+0,153=0,318 \\
& \mathrm{C}[3]=0,167+0,318=0,485 \\
& \mathrm{C}[4]=0,167+0,485=0,652 \\
& \mathrm{C}[5]=0,203+0,652=0,83 \\
& \mathrm{C}[6]=0,142+0,83=0.97=1
\end{aligned}
$$

Proses roulete-wheel adalah membangkitkan nilai acak R antara 0-1. Jika $\mathrm{R}[\mathrm{k}]<\mathrm{C}[\mathrm{k}]$ maka kromosom ke-k sebagai induk, selain itu pilih kromosom ke-k sebagai induk dengan syarat $\mathrm{C}[\mathrm{k}-1]<\mathrm{R}[\mathrm{k}]<\mathrm{C}[\mathrm{k}]$. Putar rouletewheel sebanyak jumlah kromosom yaitu 6 kali. (membangkitkan bilangan acak R).

$$
\begin{aligned}
& \mathrm{R}[1]=0,314 \\
& \mathrm{R}[2]=0,111 \\
& \mathrm{R}[3]=0,342 \\
& \mathrm{R}[4]=0,743 \\
& \mathrm{R}[5]=0,521 \\
& \mathrm{R}[6]=0,411
\end{aligned}
$$

Setelah itu, populasi baru akan terbentuk, yaitu: Kromosom[1] $=[2]=[$ D B E C $]$ Kromosom[2] $=[1]=$ $\left[\begin{array}{llll}\mathrm{B} & \mathrm{D} & \mathrm{C} & \mathrm{E}\end{array}\right]$ Kromosom[3] $=[3]=\left[\begin{array}{llll}\mathrm{B} & \mathrm{E} & \mathrm{C} & \mathrm{D}\end{array}\right]$ Kromosom $[4]=[5]=[$ C E D B] Kromosom[5] $=[4]=$ [E D B C] Kromosom[6] = [6] = [D C B E].

\section{Crossover (Pindah Silang)}

Pindah silang pada TSP dapat diimplementasikan dengan skema order crossover. Pada skema ini, satu bagian kromosom dipertukarkan dengan tetap menjaga urutan kota yang bukan bagian dari kromosom tersebut. Kromosom yang dijadikan induk dipilih secara acak dan jumlah kromosom yang dicrossover dipengaruhi oleh parameter. Crossover probability (ñc). Misal menentukan $\tilde{\text { nc }}=25 \%$, maka diharapkan dalam 1 generasi ada 50\% (3 kromosom) dari populasi mengalami crossover. Pertama membangkitkan bilangan acak R sebanyak jumlah populasi yaitu 6 kali.

$$
\begin{aligned}
& \mathrm{R}[1]=0,451 \\
& \mathrm{R}[2]=0,211 \\
& \mathrm{R}[3]=0,302 \\
& \mathrm{R}[4]=0,877 \\
& \mathrm{R}[5]=0,771 \\
& \mathrm{R}[6]=0,131
\end{aligned}
$$

Kromosom ke-k yang dipilih sebagai induk jika $\mathrm{R}[\mathrm{k}]$ < ñc. Maka yang akan dijadikan induk adalah kromosom[2], kromosom[3], dan kromosom[6]. Setelah melakukan pemilihan induk, proses selanjutnya adalah menentukan posisi crossover. Hal tersebut dilakukan dengan membangkitkan bilangan acak antara 1 sampai dengan panjang kromosom-1. Dalam kasus TSP ini bilangan acaknya adalah antara 1-3. Misal diperoleh bilangan acaknya 1, maka gen yang ke-1 pada kromosom induk pertama diambil kemudian ditukar dengan gen pada kromosom induk kedua yang belum ada pada induk pertama dengan tetap memperhatikan urutannya. Bilangan acak untuk 3 kromosom induk yang akan di-crossover :

$$
\begin{aligned}
& \mathrm{C}[2]=2 \\
& \mathrm{C}[3]=1 \\
& \mathrm{C}[6]=2
\end{aligned}
$$

Proses crossover :

Kromosom[2] = Kromosom[2] $><$ Kromosom[3]

$=[\mathrm{BD} \mathrm{CE}]\rangle\langle[\mathrm{BECD}]$

$=[\mathrm{BDEC}]$

Kromosom[3] = Kromosom[3] $><$ Kromosom[6]

$=[\mathrm{BECD}]\rangle\langle[\mathrm{DCBE}]$

$=[\mathrm{BCED}]$

Kromosom[6] = Kromosom[6] $><$ Kromosom[2]

$=[\mathrm{DCBE}]\rangle<[\mathrm{DBEC}]$

$=[\mathrm{DCEB}]$ 
Populasi setelah di-crossover :

Kromosom[1] $=[$ D B E C $]$

Kromosom[2] $=[$ B D E C $]$

Kromosom[3] $=[$ B C E D $]$

Kromosom[4] $=[$ C E D B $]$

Kromosom[5] $=[$ E D B C $]$

Kromosom[6] $=[$ D C E B $]$

\section{E. Mutasi}

Pada kasus TSP ini skema mutasi yang digunakan adalah swapping mutation. Jumlah kromosom yang mengalami mutasi dalam satu populasi ditentukan oleh parameter mutation rate(ñm). Proses mutasi dilakukan dengan cara menukar gen yang dipilih secara acak dengan gen sesudahnya. Jika gen tersebut berada di akhir kromosom, maka ditukar dengan gen yang pertama. Pertama menghitung panjang total gen yang ada pada satu populasi: Panjang total gen $=$ jumlah gen dalam 1 kromosom $*$ jumlah Kromosom $(3)=4 * 6=24$ Untuk memilih posisi gen yang mengalami mutasi dilakukan dengan membangkitkan bilangan acak antara 1 Panjang total gen yaitu 1-24. Misal menentukan ñm = $20 \%$. Maka jumlah gen yang akan dimutasi adalah = $0,2 * 24=4,8=5$. Lima buah posisi gen yang akan dimutasi, setelah diacak adalah posisi 3, 7, 10, 20, 24.

Proses mutasi :

Kromosom $[1]=[\mathrm{D}$ B C E $]=[\mathrm{D}$ B C E $]$

Kromosom[2] $=[$ B D E C $]=[$ B D C E $]$

Kromosom $[3]=[$ B C E D $]=[$ B E C D $]$

Kromosom $[4]=[$ C E D B $]=[$ C E D B $]$

Kromosom $[5]=[$ E D B C $]=[$ C D B E $]$

Kromosom $[6]=[\mathrm{D} \mathrm{C} \mathrm{E} \mathrm{B}]=[\mathrm{B}$ C E D $]$

Proses algoritma genetik untuk 1 generasi telah selesai. Maka nilai fitness setelah 1 generasi adalah:

- Fitness $[1]=\mathrm{AD}+\mathrm{DB}+\mathrm{BC}+\mathrm{CE}+\mathrm{EA}=1.8+1.2+2.1$ $+2.2+2=9.3$

- Fitness[2] = AB+BD+DC+CE+EA $=0.7+1.2+0.8$ $+2.2+2=6.9$

- Fitness $[3]=\mathrm{AB}+\mathrm{BC}+\mathrm{CE}+\mathrm{ED}+\mathrm{DA}=0.7+2.1+2.2$ $+1.3+1.8=8.1$

- Fitness[4] = AC+CE+ED+DB+BA $=0.9+2.2+0.6$ $+1.2+0.7=5.6$

- Fitness $[5]=\mathrm{AE}+\mathrm{ED}+\mathrm{DB}+\mathrm{BC}+\mathrm{CA}=1.8+1.3+1.2$ $+2.1+0.9=7.3$

- Fitness[6] $=\mathrm{AD}+\mathrm{DC}+\mathrm{CE}+\mathrm{EB}+\mathrm{BA}=1.8+0.8+2.2$ $+1.3+0.7=6.8$

TABEL II

RATA - RATA HASIL NILAI FITNES

\begin{tabular}{|c|c|c|}
\hline Generasi Ke & Fitness Tertinggi & Fitness Terendah \\
\hline 1 & 7,4 & 5,6 \\
\hline 2 & 9,3 & 5,6 \\
\hline
\end{tabular}

\section{KESIMPULAN}

Pada penelitian ini mendapatkan hasil penentuan jalur pada fitness gen pertama mendapatkan fitness tertinggi 7.4, fitness terendah 5.6 dan pada gen kedua mendapatkan fitness tertinggi 9.3, fitness terendah 5.6. Jadi ditentukan kriteria berhenti yaitu bila setelah dalam beda generasi berturutturut diperoleh nilai fitness yang terendah tidak berubah. Pada 1 generasi telah terlihat bahwa terdapat nilai fitness terkecil yang tidak berubah. Apabila perhitungan dilanjutkan hingga ke generasi ke-N maka diyakinkan bahwa nilai fitness yang terendah tetap tidak akan berubah. Walaupun perhitungan cukup dijabarkan hingga generasi ke-1 saja namun solusi yang mendekati optimal telah didapatkan. Oleh karena itu, terbukti bahwa algoritma genetika dapat menyelesaikan persoalan TSP.

\section{REFERENSI}

[1] I. Maryati and H.K. Wibowo, "Optimasi Penentuan Rute Kendaraan pada Sistem Distribusi Barang dengan Ant Colony Optimization,” p.6, 2012

[2] H. Nirwansyah and Widowati, "Efisiensi Biaya Distribusi dengan Metode.pdf," 2007.

[3] H.L. Suwarno, "Sembilan Fungsi Saluran Distribusi: Kunci Pelaksanaan Kegiatan Distribusi yang Efektif," J.Manaj., vol. 6, no. 1, p. 9, 2006.

[4] Joni, I.D.M, and Nurcahyawati V, "Penentuan Jarak Terpendek pada Jalur Distribusi Barang di Pulau Jawa dengan Menggunakan Algoritma Genetika (3)," Jurnal Nasional Pendidikan Teknik Informatika., vol. 1, no.3, 2012.

[5] S. Fachrurrazi, "Penerapan Algoritma Genetika dalam Optimasi Pendistribusian Pupuk di PT. Pupuk Iskandar Muda Aceh Utara," Jurnal Techsi, vol. 2, no. 1, p. 20, 2013.

[6] A.W. Annasir, "Implementasi Algoritma Genetika untuk Pencarian Rute Berdasarkan Waktu Tercepat Objek Wisata di Kabupaten Ngawi," p. 12, 2013.

[7] Minaryo, Rudi, and Saptaningtyas, "Algoritma Genetika dengan Metode Roulette Wheel Selection dalam Optimasi Pendistribusian Barang di PT. Fastra Buana Yogyakarta,", Lumbung Pustaka UNY.html., 2016

[8] Vnp, "Roulette Wheel Selection," Ambon Memanggil, 28-Apr-2009.

[9] N.L.A. Ayuningrum and F.Y. Saptaningtyas. "Implementasi Algoritma Genetika dengan Variasi Crossover dalam Penyelesaian Capacitated Vehicle Routing Problem with Time Windows (CVRPTW) pada Pendistribusian Air Mineral," p. 11, 2017.

[10] Y.K. Hartono, “Tipe-Tipe Data Oracle 11g,” p. 18, 2011. 